\title{
DESIGN AND TESTING OF AUTOMOBILE EXHAUST SYSTEM
}

\author{
Akshay Tajane', Mahesh Jadhav², Rumdeo Rathod ${ }^{3}$, Vilas Elavande ${ }^{4}$ \\ ${ }^{1}$ Assistant Professor, Mechanical Engineering, LGN Sapkal COE, Nashik, Maharashtra, India \\ ${ }^{2}$ Assistant Professor, Mechanical Engineering, LGN Sapkal COE, Nashik, Maharashtra, India \\ ${ }^{3}$ Assistant Professor, Mechanical Engineering, LGN Sapkal COE, Nashik, Maharashtra, India \\ ${ }^{4}$ Assistant Professor, Mechanical Engineering, LGN Sapkal COE, Nashik, Maharashtra, India
}

\begin{abstract}
The aim of this paper is to provide deeper understanding of the dynamics of automobile exhaust system to provide a basis for the improved design \& development of computationally inexpensive theoretical system model. Modeling, simulation \& experimental investigation of a typical exhaust system are performed to gain such an understanding \& to evaluate modeling ideas. These models incorporate adjustable flexibility in their connection to the exhaust pipes \& a procedure is developed for automatic updating of these parameters to obtain better correlation with experimental results. The agreement between the simulation results of the updated models \& experimental results is very good, which confirms the usability of these models. The main objective of this project is to design exhaust system and to compare its performance with an existing system available. The newly designed exhaust system shows lower back pressure which ultimately results better performance of the engine. Low vibration levels are critical to achievee in automobile exhaust system. It is therefore important design engineers to be able to predict, explain \& assess the dynamics of various system design proposals during product development.
\end{abstract}

Keywords: Automobile Exhaust system, Analysis, Testing

\section{INTRODUCTION}

An automobile Exhaust system consisting exhaust pipe, muffler, is used for silencing the noise caused by high pressure exhaust gases leaving the engine \& for transporting these hot \& toxic gases away from vehicle. It is also an important \& integral part of combustion \& emission control. For this to work properly there must be no leakage upstream of the catalytic converter. The durability of that part of the system is therefore crucial. Customer demands for comfort \& long product life guarantee also for the exhaust system as a whole are additional reasons for the increasing importance for design engineers to be able to predict, describe $\&$ assess the dynamics of various system design proposals during product development.

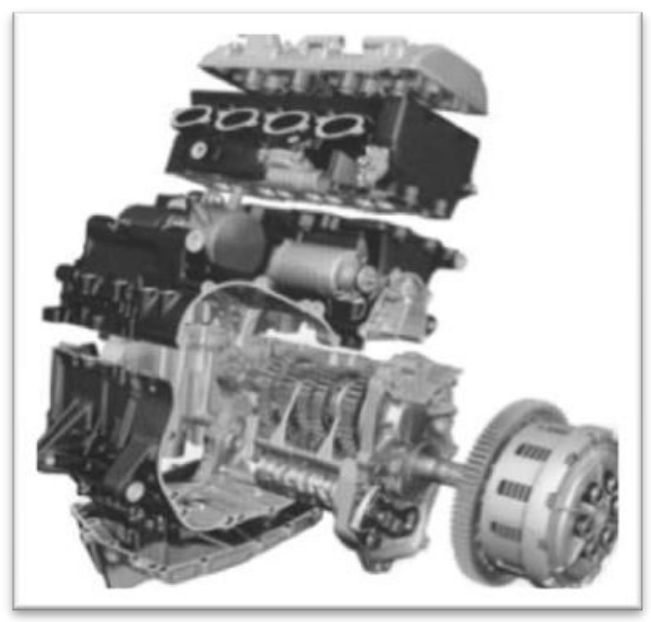

Fig.1.1 Engine requirements
Design involves identification of the main geometric characteristics on which the behavior of the muffler, most notably, longitudinal or transversal propagation directions and their associated lengths depends. Ideally, this information should be obtained from experimental parametric studies performed in controlled conditions and sufficiently representative of the real exhaust working conditions.

The principal aim achieved from the this work was the development of an design procedure for the vehicle exhaust system, according to the following industrial requirements:

1. a durability of the exhaust system downstream of the catalytic converter equal to $80,000 \mathrm{~km}$ or 6 years, with design procedure optimization and the use of new materials having a cost as low as possible

2. 2-way catalyst having a conversion efficiency drop not higher than $15 \%$ at the end of the useful car life;

3. The secondary objective of the work concerned the reduction of the exhaust system design costs and time to market.

4. It has been proved that these tools - simulation methods, computational procedures and design guidelines - can be used as design tools for exhaust systems.

\section{ANALYSIS AND MODELLING OF EXHAUST SYSTEM}

The diameter of the inlet pipe is taken same as the diameter of the exhaust port of the engine. The length of the inlet pipe is taken as small as possible so that muffler will occupy less 
space. There is no specific procedure for designing inlet pipe of the muffler. It is designed empirically.

\section{Design of expansion chamber:}

As expansion chamber is of reactive type. It is most effective at low frequencies. i.e. less than $500 \mathrm{c} / \mathrm{s}$ and $\mathrm{m}=10$ $\mathrm{D}=$ Diameter of the expansion chamber

$\mathrm{d}=$ diameter of the inlet pipe.

Here the diameter of the inlet pipe $=0.0603$ i.e. $d=0.0603 \mathrm{~m}$ $\mathrm{m}=10$ (assumed)

$\mathrm{D}^{2}=\mathrm{m} \mathrm{d}^{2}$

$\mathrm{D}=(10) 1 / 2 * 0.0603=0.20 \mathrm{~m}$

The normal practice is to adopt the length of the chamber 10 to 12 times the diameter of the exhaust pipe.

i.e. $1=(10$ to 12$) \mathrm{d}$

Let us take $1=12 \mathrm{~d}, 1=12 * 0.0635=0.762 \mathrm{~m}$

$1=0.75 \mathrm{~m}$ (approximately)

Volume of the expansion chamber

$\mathrm{Vm}=\mathrm{d}^{2} * 1$

$=0.785 *(0.2) 2 * 0.75$

$\mathrm{Vm}=0.02355 \mathrm{~m} 3$

Design of outlet pipe:

The outlet pipe dimensions are same as that of the inlet pipe. The outlet pipe is also termed as tail pipe. The diameter of the outlet pipe is taken as $0.0635 \mathrm{~m}$ and length of the outlet pipe is $0.2 \mathrm{~m}$.

\subsection{Design Consideration}

Well-designed exhaust systems collect exhaust gases from engine cylinders and discharge them as quickly and silently as possible. Primary system design considerations include:

1. Minimizing resistance to gas flow (back pressure) and keeping it within the limits specified for the particular engine model and rating to provide maximum efficiency.

2. Reducing exhaust noise emission to meet local regulations and application requirements.

3. Providing adequate clearance between exhaust system components and engine components, machine structures, engine bays, enclosures and building structures to reduce the impact of high exhaust temperatures on such items.

4. Ensuring the system does not overstress engine components such as turbochargers and manifolds with excess weight. Overstressing can shorten the life of engine components.

5. Ensuring the exhaust system components are able to reject heat energy as intended by the original design.

\subsection{Initial Finite Element Model:}

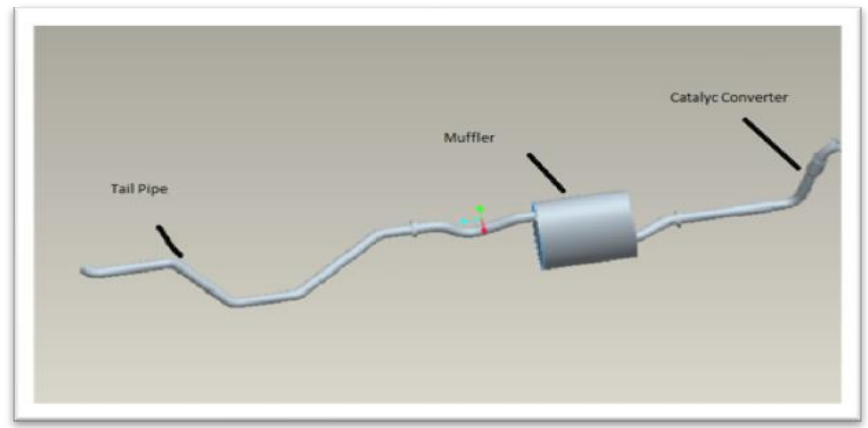

Fig. 2.1: Cad Model: Assembly of Exhaust System

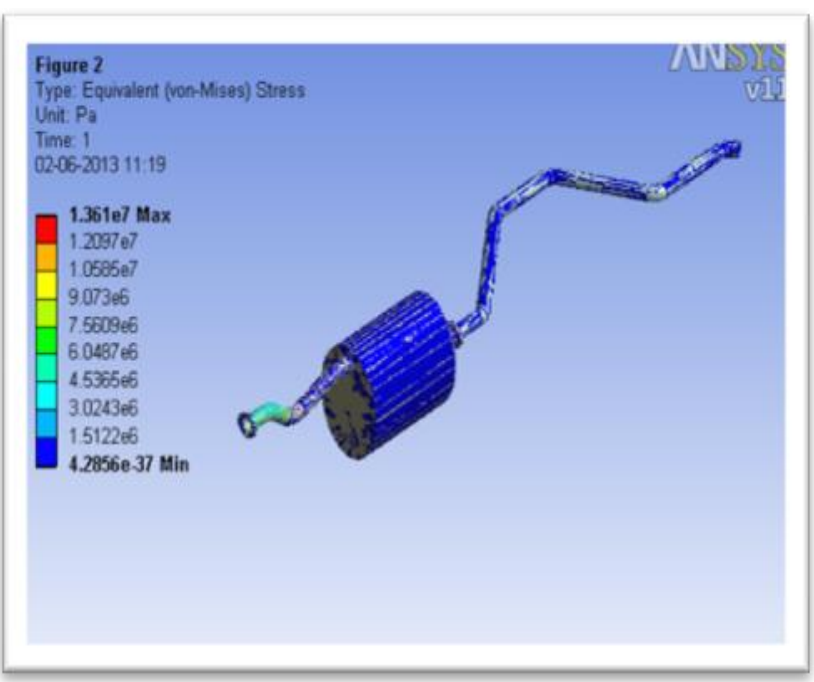

Fig. 2.2: FEA Analysis of Exhaust System

Table 1: Nodal Analysis

\begin{tabular}{|l|l|}
\hline Mesh type & Solid Mesh \\
\hline Analysis type & Contact analysis \\
\hline Total Node & 53238 \\
\hline Total Elements & 24932 \\
\hline
\end{tabular}

From the FE analysis it is clear that when a gas pressure of $3 \times 105 \mathrm{~Pa}$ is applied inside the exhaust system \& vertical force of $150 \mathrm{~N}$ is applied as clamp force on exhaust pipes, maximum deformation of $0.0001 \mathrm{~m}$ is observed which is tolerable. Max. Von misses stress induced at this load is $1.36 \times 107 \mathrm{~Pa}$ which is less than tensile yield strength of Stainless Steel 2.5 x $108 \mathrm{~Pa}$. Hence design is safe. 


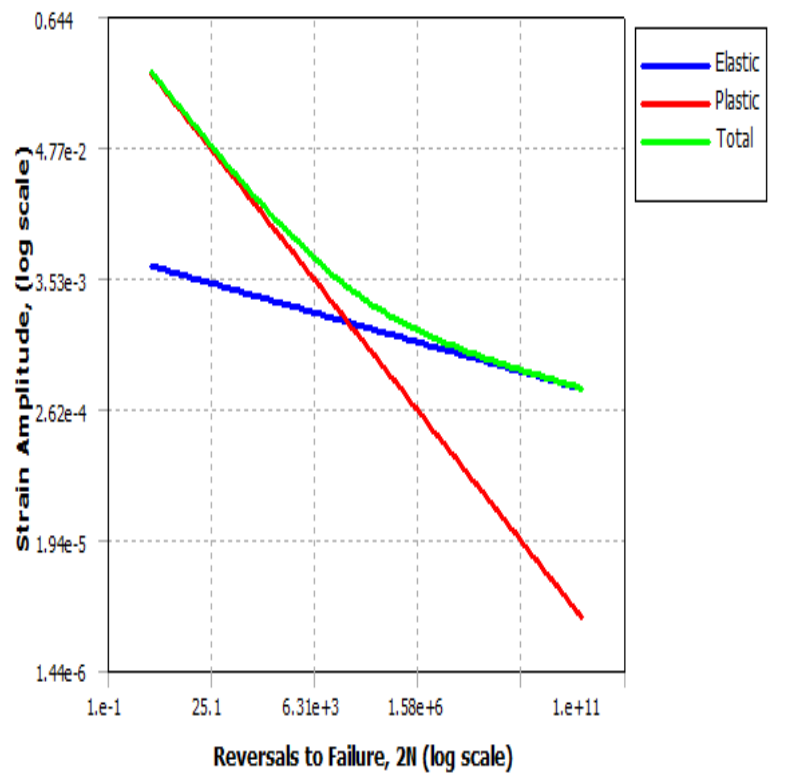

Fig.2.4 Strain Vs Reverses of Failure

Optimize the muffler which is subjected to the internal pressure of $3.5 \mathrm{~N} / \mathrm{mm} 2$. The mass of the empty vessel should not exceed $8 \mathrm{~kg}$. If the factor of safety is 3.0 , design with the objective of maximizing the gas storage capacity.

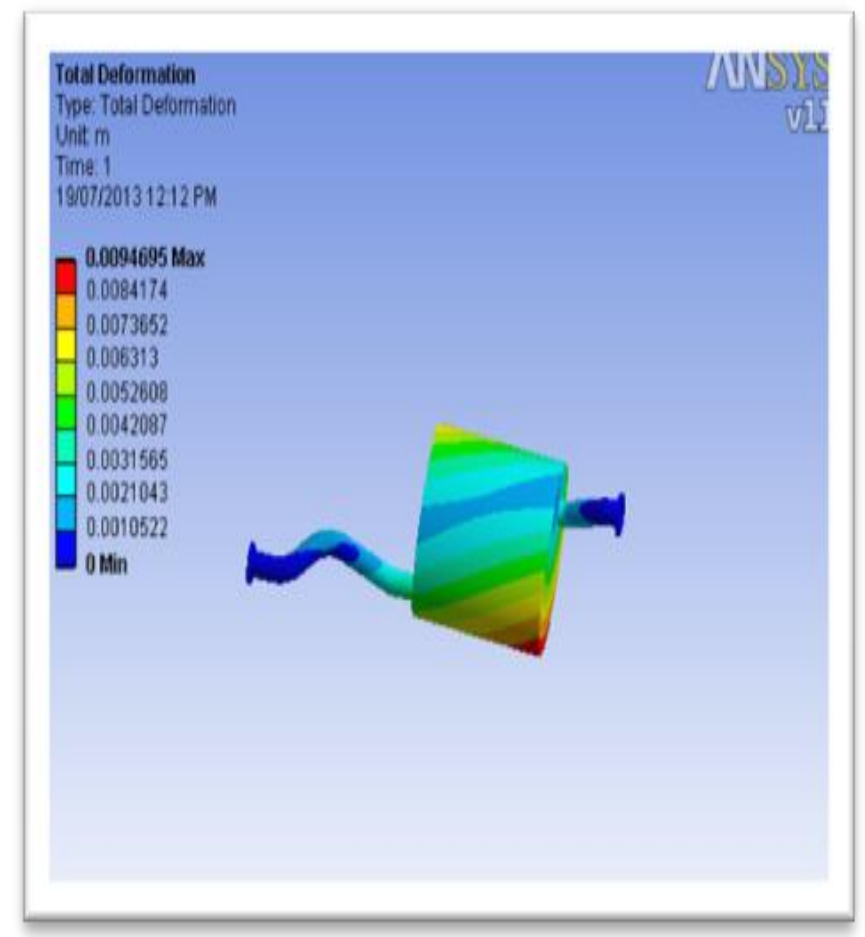

Fig. 2.5: Deformation Of Optimized Muffler

\section{VARIOUS TESTS ON EXHAUST SYSTEM}

\subsection{Material Testing}

Material testing was done on UTM, it can be said that material chosen for the current system is appropriate \& material has good properties to withstand under working condition.
First the sample is loaded on UTM on tension side \& fixed between the jaws. The capacity of UTM was 40 tonne. It is made sure that both valves of hydraulic unit of machine are closed.

Then the machine is started $\&$ in the machine control unit type of test was set as tensile test.

Specimen dimensions are entered in machine control unit \& then by making the hydraulic power on the right side valve was opened.

Then the jaws move in opposite direction hence the tension come on specimen. Machine control unit shows the applied load \& elongation after application of load. When maximum tension comes, specimen get fractured .At that time results are stored by pressing 'store result' button in machine control unit.

By pressing the view result button, results like yield load, ultimate load, Final gauge length, yield strength, UTS are are noted.

Table 2: SS 60.3 Diameter Pipe Tension Test Report

\begin{tabular}{|l|l|l|l|}
\hline Parameter & Unit & Value & $\begin{array}{l}\text { Required } \\
\text { Value }\end{array}$ \\
\hline Width & $\mathrm{mm}$ & 20.00 & -- \\
\hline Thickness & $\mathrm{mm}$ & 1.5 & -- \\
\hline Area & $\mathrm{mm}^{2}$ & 30.00 & -- \\
\hline Gauge Length & $\mathrm{mm}$ & 50.00 & -- \\
\hline Yield Load & $\mathrm{kN}$ & 6.80 & -- \\
\hline Ultimate Load & $\mathrm{kN}$ & 12.40 & -- \\
\hline $\begin{array}{l}\text { Final Gauge } \\
\text { Length }\end{array}$ & $\mathrm{mm}$ & 64.00 & -- \\
\hline Yield Strength & $\mathrm{N} / \mathrm{mm}^{2}$ & 226.67 & $175.0 \mathrm{Min}$. \\
\hline U.T.S. & $\mathrm{N} / \mathrm{mm}^{2}$ & 413.33 & 360.0 Min. \\
\hline
\end{tabular}

\subsection{Leak Test}

Procedure:-Fasten the component on checking fixture. Close both ends of components with rubber hose. Start the pneumatic system so that pressurized air at a pressure of 6 bar will pass through the component $\&$ note that pressure gauge will not exceed limit of 6 bar. Check leakage rate on digital meter. Note down the leakage rate $\&$ if the leakage rate is more than allowable leakage rate then reject the component otherwise accept it. For different components different allowable leakage rate are there. 


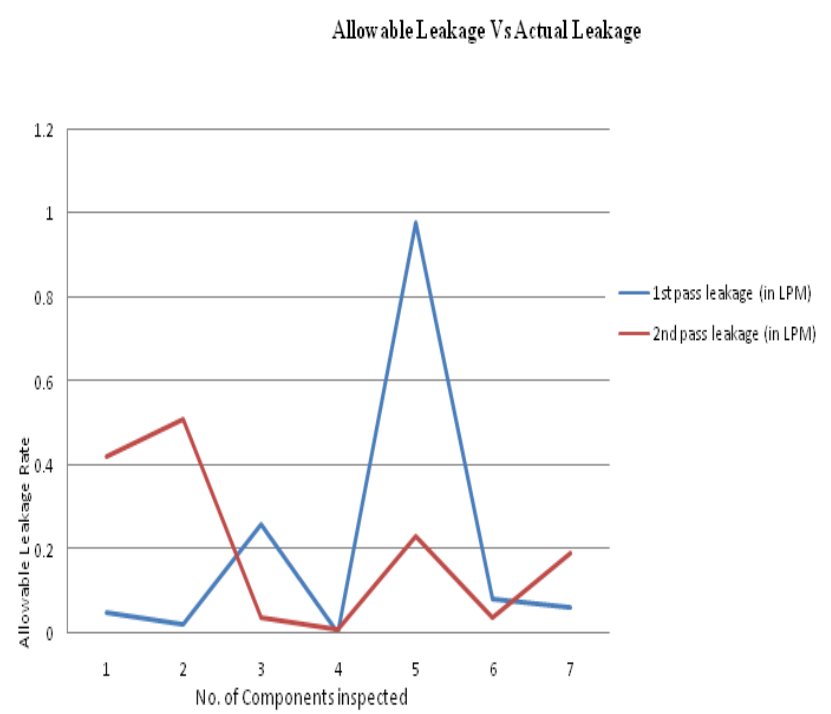

Graph 3.1 Comparison of Results

If the component has more pressure drop in leak test, then it is again rewelded at the joint where leakage is more or it is rejected.

\subsection{Weld Test:}

The parameters which are tested in weld test are:
1. Penetration Length
2. Penetration depth
3. Gap
4. Groove thickness
5. Material Thickness
6. Bid angle

Table 3: Test Report for Bracket+ Pipe

\begin{tabular}{|c|c|c|c|c|}
\hline Description & & $\begin{array}{l}\text { Required } \\
\text { Parameters }\end{array}$ & $\begin{array}{l}\text { Measured } \\
\text { Values }\end{array}$ & $\begin{array}{l}\text { Rem- } \\
\text { arks }\end{array}$ \\
\hline $\begin{array}{l}\text { 1.Penetration } \\
\text { Length }\end{array}$ & L1 & \multirow[t]{2}{*}{$\mathrm{L} 1, \mathrm{~L} 2>\mathrm{e}$} & $6.991 \mathrm{~mm}$ & ok \\
\hline $\begin{array}{l}\text { 2.Penetration } \\
\text { Length }\end{array}$ & L2 & & $7.394 \mathrm{~mm}$ & ok \\
\hline $\begin{array}{l}\text { 3.Groove } \\
\text { Thickness }\end{array}$ & G & $\mathrm{G}>\mathrm{e}$ & .... $\mathrm{mm}$ & $\ldots \ldots$ \\
\hline 4. Gap & $\mathrm{b}$ & $\begin{array}{l}\mathrm{b}<0.5 \mathrm{~mm} \\
\text { for } \mathrm{e} \leq \\
1.15 \mathrm{~mm} \text { or } \\
\mathrm{b}<0.7 \mathrm{~mm} \\
\text { for } \\
1.15 \mathrm{~mm}<\mathrm{e} \\
\leq 1.5 \mathrm{~mm}\end{array}$ & $3.709 \mathrm{~mm}$ & $\begin{array}{l}\text { Not } \\
\text { ok }\end{array}$ \\
\hline $\begin{array}{l}\text { 5.Penetration } \\
\text { Depth }\end{array}$ & P1 & $\begin{array}{l}0.2 \mathrm{~mm}<\mathrm{P} 1, \\
\mathrm{P} 2<\mathrm{e} 1, \mathrm{e} 2\end{array}$ & $1.486 \mathrm{~mm}$ & ok \\
\hline $\begin{array}{l}\text { 6.Penetration } \\
\text { Depth }\end{array}$ & $\mathrm{P} 2$ & $\begin{array}{l}0.2 \mathrm{~mm}<\mathrm{P} 1, \\
\mathrm{P} 2<\mathrm{e} 1, \mathrm{e} 2\end{array}$ & $1.327 \mathrm{~mm}$ & n...... \\
\hline $\begin{array}{l}\text { 7.Seam/Part } \\
\text { Connection } \\
\text { Angle }\end{array}$ & $\begin{array}{l}\alpha \\
\beta\end{array}$ & \multirow[t]{2}{*}{$\begin{array}{l}\alpha, \quad \beta> \\
110^{\circ}\end{array}$} & $\begin{array}{l}170.89 \\
\text { deg }\end{array}$ & ok \\
\hline $\begin{array}{l}\text { 8.Seam/Part } \\
\text { Connection } \\
\text { Angle }\end{array}$ & $\begin{array}{l}\alpha \\
\beta\end{array}$ & & $\begin{array}{ll}\text { 151. } & 97 \\
\text { deg } & \end{array}$ & ok \\
\hline
\end{tabular}

\begin{tabular}{|l|l|l|l|l|}
\hline $\begin{array}{l}\text { 9. Thickness Of } \\
\text { Welded Parts }\end{array}$ & e1 & ---- & $1.622 \mathrm{~mm}$ & ok \\
\hline $\begin{array}{l}\text { 10.Thickness Of } \\
\text { Welded Parts }\end{array}$ & e2 & ---- & $2.975 \mathrm{~mm}$ & ok \\
\hline 11. Undercut & r1 & r1 $<0.1 \mathrm{e} 1$ & $\ldots \ldots \mathrm{mm}$ & $\ldots \ldots$ \\
\hline 12. Undercut & r2 & r2 $<0.1 \mathrm{e} 2$ & $\ldots \ldots \mathrm{mm}$ & $\ldots \ldots$ \\
\hline
\end{tabular}
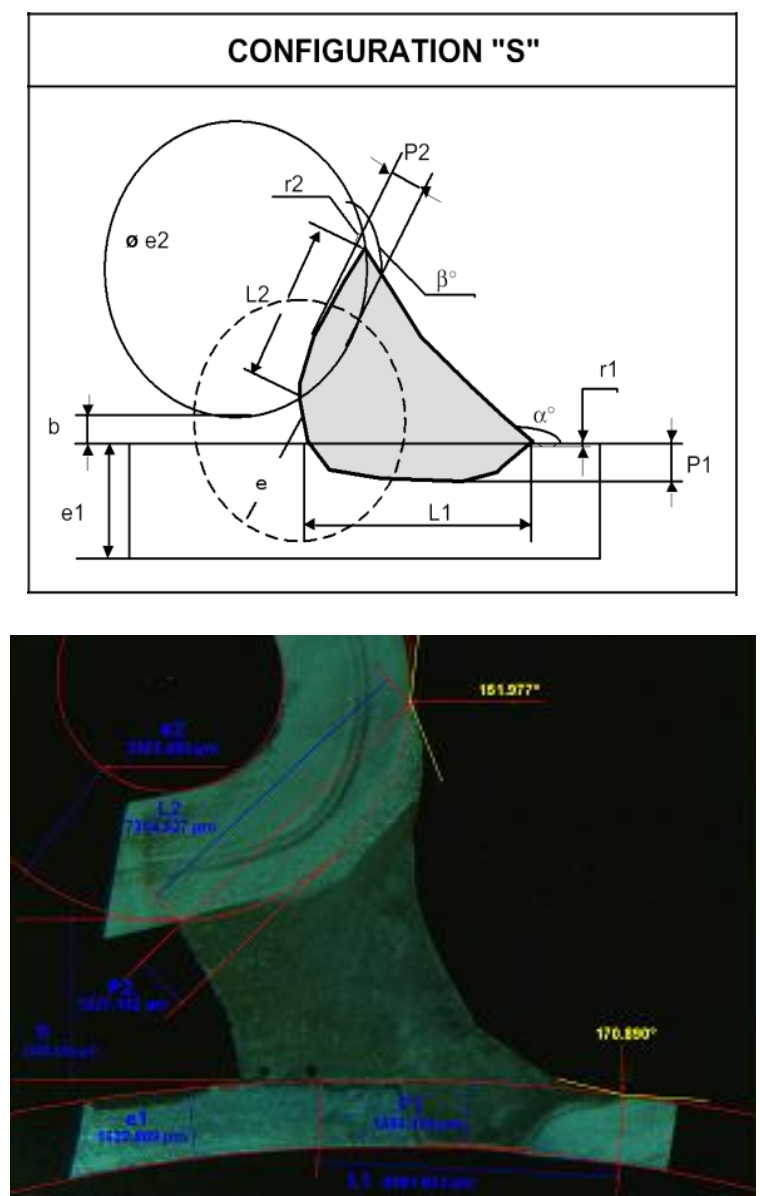

Fig. 6.6: Macro Test for Bracket+ Pipe

\section{CONCLUSIONS}

Dynamics of an automobile exhaust system is the subject of this work. The investigation shows that the exhaust system is essentially linear downstream of the flexible joint. Highly simplified finite element models of the major components are made. These models incorporate adjustable flexibility in their connection to the exhaust pipes, and a procedure is developed for automatic updating of these parameters to obtain better correlations with experimental results. The agreement between the simulation results of the updated models \& the experimental results is very good, which confines the usability of these models.

Material test suggest that material chosen (SUS 409 S.S.) is suitable for this system. Transmission loss test suggests that max. transmission loss through the system is $13.12 \mathrm{~dB} \&$ is less. Leak test suggests that actual leakage rate is less than allowable leakage rate. According to weld test, the parameters which are tested are in specified range hence it can be stated that welds in the system have good quality. 


\section{ACKNOWLEDGMENTS}

It is my proud privilege to express deep sense of gratitude to, Prof. A.G. Thakur, H.O.D., Mechanical Engg. Department, SRES C.O.E. Kopargaon, Maharashtra for his comments and kind permission to complete this work. I remain indebted to Prof. S.V. Bhaskar (Project guide), for their timely suggestions and valuable guidance.

I am thankful to Mr. Shrinivasan (Production Manager) \& Mr. Kishor Jadhav(Asstt. Manager-Development) from Sharda Motor I. Ltd., Satpur, Nashik for their valuable guidance $\&$ help regarding completion of this work

\section{REFERENCES}

[1]. M.Rajasekhar Reddy, Dr K.Madhava Reddy, “ Design \& Optimization of Exhaust Mufflers in Engine", 'International Journal of Engineering Research \& Applications', Sept-Oct 2012, Vol.2, Issue-5,pp. 395 to 398 [2]. A. R. Mohanty ,S. P. Pattnaik, "An Optimal Design Methodology for a Family of Perforated Mufflers", " Symposium on International Automotive Technology', 2005, Vol.-26, 053,pp 637-645

[3]. A.R. Palaniappan, Sabha Manigantan, "Design Of Exhaust System In Automobiles With Low Carbon Economy", 'International Journal of Mechanical and Production Engineering',2013,Volume-1, Issue-1,pp 6-9

[4]. Min-Chie Chiu, "Numerical Optimization Of A ThreeChamber Muffler Hybridized With A Side Inlet And A Perforated Tube By SA Method", 'Journal of Marine Science and Technology' ,2010, Vol. 18, No. 4, pp. 484-495 [4]. R. S. Khurmi, J. K. Gupta, "Machine Design", Eurasia Publishing House, 2005

\section{BIOGRAPHIES}

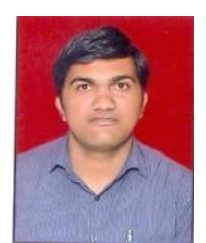

Prof. Tajane A. G. is a Mechanical Engineer (B.E. Mechanical, 2005, M.E. Design, 2013) from University of Pune. $\mathrm{He}$ is in the Department of Mechanical Engineering at the LGN Sapkal College of Engineering (Nashik at present) and working as an Assistant professor. He has 6 years teaching experience and 3 years industrial experience.

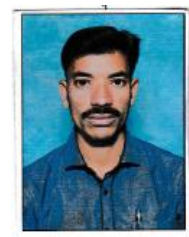

Prof. Jadhav M. V. is a Mechanical Engineer (ME Design) from University of Pune. He is in the Department of Mechanical Engineering at the LGN Sapkal College of Engineering (Nashik at present) and working as an Assistant professor. He has 4 years teaching experience.

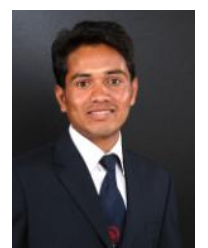

Prof. Rathod. R. B. is a Mechanical Engineer, B.E. Mechanical from University of Pune \& he has done M.Tech. CAD/CAM from Symboisis University.. $\mathrm{He}$ is in the Department of Mechanical Engineering at the LGN Sapkal College of Engineering (Nashik at present) and working as an Assistant professor. He has 3 years teaching experience.
Prof. Elavande V. U. is a Mechanical Engineer (ME Heat Power) from University of Pune. He is in the Department of Mechanical Engineering at the LGN Sapkal College of Engineering (Nashik at present) and working as an Assistant professor. He has 4 years teaching experience. 